\title{
Growth strategies of an abundant reef-building coral in the southern Caribbean (Undaria tenuifolia)
}

\author{
Silvia Marcela Cáceres ${ }^{1,2}$, Juan Armando Sánchez ${ }^{1, *}$ \\ ${ }^{1}$ Laboratorio de Biología Molecular Marina -BIOMMAR, Departamento de Ciencias Biológicas, \\ Facultad de Ciencias, Universidad de los Andes, Bogotá, COLOMBIA \\ ${ }^{2}$ Current address: Department of Medicine, National Jewish health, Denver, CO, USA
}

\begin{abstract}
The Caribbean coral community structure is changing, particularly species dominance. The Acropora die-off, at many southern and western Caribbean reefs, has allowed the branching scleractinian coral Undaria tenuifolia Dana to become one of the dominant species in these shallow reefs. In this study, colonies of $U$. tenuifolia were followed for a year using digital imagery. We developed a size class model that allowed us to estimate population fluctuation and growth strategies (colony growth rates and clonal processes). Growth rates varied with colony size; mid-sized colonies doubled their size in a year, while larger colonies often undergo fission. The clonal strategies, i.e., fusion and fission, allow $U$. tenuifolia to compensate for the low survival rates of early larval post-settlement thus being able to become a dominant coral species in the current reef scenario. The size matrix model formulated on the basis of a relative colony growth rate offered a practical approach for a short-term observation situation, generating a "timeinvariant” transition model. Mortality patterns were not correlated to size classes and were variable by location and time. Overall, population abundance was stable over the monitored period of time. The high survivorship of $U$. tenuifolia after clonal fragmentation, as well as its high growth rate, suggests that this is a potential species to be cultured, which could be a solution given that this species has become the most common coral being extracted and sold as a souvenir in Cartagena, Colombia.
\end{abstract}

Key words: Agaricia, Undaria tenuifolia, clonal, community structure shifts, colonial growth, Caribbean Sea, coral reefs, coral extraction.

Estrategias de crecimiento de un abundante coral formador de arrecifes en el Caribe sur (Undaria tenuifolia)

\section{Resumen}

La estructura de las comunidades coralinas del mar Caribe está cambiando, sobre todo en cuanto a especies dominantes. Particularmente la mortandad de Acropora, en muchos arrecifes del sur y oeste del Caribe, ha permitido que el coral escleractínio Undaria tenuifolia Dana se convierta en una de las especies dominantes en los arrecifes someros. En este estudio, se le hizo seguimiento a colonias de $U$. tenuifolia, durante un año mediante el uso de imágenes digitales. Se desarrolló un modelo de clases de tamaño que permite estimar la fluctuación poblacional y determinar la estrategia de crecimiento. El modelo de clases de tamaño calcula las tasas de crecimiento de las colonias así como los procesos clonales. La clase de tamaño de la colonia afecta la estrategia de crecimiento de esta, donde colonias medianas pueden duplicar su tamaño en un año mientras las colonias más grandes generalmente se dividen. Las estrategias clonales, e.g., fisión y fusión, observadas durante el período de estudio, le permiten a $U$. tenuifolia sobreponerse a las bajas tasas de sobrevivencia del asentamiento post-larval, además de convertirla en una especie de coral dominante. La matriz del modelo de tamaños formulado a partir del crecimiento relativo de la colonia ofrece un enfoque práctico para observaciones a corto plazo, generando a su vez un modelo de transición “invariante en el tiempo". Los patrones de mortalidad no se correlacionaron con clases de tamaño y fueron variables según el lugar y el tiempo. La abundancia total de la población se mantuvo estable durante el período de seguimiento. La alta sobrevivencia de esta especie luego de fragmentación clonal, así como su alta tasa de crecimiento, sugieren que se trata de un coral con potencial de ser cultivado, lo que surge como una solución frente a la extracción y comercialización de esta especie como suvenir en Cartagena, Colombia.

Palabras clave: Agaricia, Undaria tenuifolia, clonal, estructura comunitaria, crecimiento colonial, mar Caribe, arrecifes coralinos, extracción coralina. 


\section{Introduction}

In the last decades, Caribbean coral reefs have declined severely, producing shifts in the coral community structure, which have not been completely understood (Aronson et al., 2002a, 2000; Hughes et al., 2003). Natural catastrophes and human activities have a dramatic impact in the coral reef community (Glynn, 1984), which affect dominant species, as observed during the mass bleaching event of Belize in 1997-98 and the Caribbean-wide events of 2005 and 2010 (Aronson \& Precht, 2000; Aronson et al., 2000; Eakin et al., 2010; Guest et al., 2012; Wilkinson \& Souter, 2008). In order to conserve and protect coral reefs, it is of great importance to identify the ecology and evolution of dominant main framework architects of coral reefs. In the Colombian Caribbean (Cartagena area), Undaria tenuifolia Dana (previously assigned to Agaricia), also known as lettuce coral (Figure 1), is today the dominant coral species in shallow semi-exposed reefs (Camargo et al., 2009; DíazPulido et al., 2004; López-Angarita et al., 2014; Restrepo et al., 2006; Sánchez, 1995). This dominance seems to extend at least from historical times, as whole coral reefs uplifted by tectonic activity between $500 \mathrm{AD}$ and $1500 \mathrm{AD}$ exhibit U. tenuifolia-dominated reefs (e.g., Isla Tesoro, Cartagena: Sánchez, 1995; Vernette et al., 1992). There is a recent dominance shift observed during the mid-1990s in Belize, where $U$. tenuifolia presented lagoonal reef dominance levels as high as 85\% after the massive mortality of the staghorn coral, Acropora cervicornis, from white band disease (Aronson et al., 2002b; Aronson \& Precht, 1997, 2000; Aronson et al., 1998, 2002c; Sebens et al., 2003). A pattern that has been also observed in some Colombian reefs after the 1983-84 Acropora die-off (Cendales et al., 2002). This sudden dominance of $U$. tenuifolia was ascribed to its "weedy" behavior due to clonal strategies and fast growth rates (Aronson et al., 2002b; Bellwood et al., 2004; Jackson, 2001).

Clonal processes are common in many reef-building corals. The two most known clonal processes are fission and fusion. Briefly, fission is caused by partial loss of tissue (partial mortality) and by fragmentation (which is a form of asexual reproduction), whereas fusion is the aggregation of ramets, likely from the same original genet, forming structures that are called "rugs". In general, clonal rocesses are found in organisms such as foliaceous and branching corals, bryozoans and plants (Aronson \& Precht, 1995; Clark-Tapia et al., 2005; Highsmith, 1982; Hughes, 1984; Hughes \& Jackson, 1985). In the case of U. tenuifolia, a foliaceous coral, clonal processes are regularly observed in the population (Hughes \& Jackson, 1980). Largely, cloning grants corals a suite of special demographic and survival

\footnotetext{
*Corresponding author:

Juan Armando Sánchez, juansanc@uniandes.edu.co

Recibido: 7 de febrero de 2015

Aceptado: 2 de agosto de 2015
}

characteristics, including the capability for fast colonization produced by an overall net growth. Net growth is defined as the balance between the addition and loss of coral polyps or modules (Highsmith, 1982; Hughes \& Jackson, 1985). Clonal processes introduce a trade-off between genotype expansion and genetic diversity reduction (Foster et al., 2013; Vollmer \& Palumbi, 2006). Indeed, genetic uniformity could make coral populations more susceptible to physiological stress by lowering their ability to adapt to environmental changes (Hughes et al., 2003; Lasker \& Coffroth, 1999; Soong, 1991; Soong \& Lang, 1992).

Studies describing growth and population dynamics of corals have uncovered dynamic patterns characteristic for each species, including a variety of recruitment, growth and mortality rates (Hughes \& Jackson, 1985; Lasker, 1990, 1991; Riegl et al., 2009; Tanner, 1997; Yoshioka, 1994). Previous studies have found that most coral populations remained stable through the period of time they were tracked (Brazeau \& Lasker, 1992; Chadwick-Furman et al., 2000; Hughes \& Jackson, 1985; Langmead \& Sheppard, 2004). In fact, pioneer studies of a congener species, $U$. agaricites, showed dynamic and variable clonal processes at the colonial level, but the structure of the overall population seemed to remain stable after a few years (Hughes, 1984).

In some localities of the Southern Caribbean, such as Cartagena, Colombia, U. tenuifolia is currently extracted and sold by locals as a souvenir (personal observation, 2005-2015). This extraction needs an evaluation from the conservation point of view in order to establish if the extraction could threaten the species' sustainability. A study of the growth rates of the species is also needed to estimate the impact of this activity. The aim of the present study is to examine the species growth strategies, i.e., growth rates and clonal processes, of an U. tenuifolia population over a year and a half at two local reefs near Cartagena. Also, it aims to understand the continued local success of this species, and its current success in areas where branching acroporids have almost disappeared.

\section{Methods}

\section{Study sites}

Two locations with a high abundance of $U$. tenuifolia were haphazardly chosen and permanently marked with concrete blocks poled with polyvinyl chloride (PVC) tubes, in order to study its growth strategies and demography. The two nearby sites are called by local divers as Palo $\left(10^{\circ} 16^{\prime}\right.$ 44.3' $\left.\mathrm{N} 75^{\circ} 35^{\prime} 50.7^{\prime \prime} \mathrm{W}\right)$ and Playita (10 $10^{\circ} 47.7^{\prime \prime} \mathrm{N}$, $\left.75^{\circ} 35^{\prime} 50.1^{\prime \prime} \mathrm{W}\right)$, off Barú island, Cartagena, Colombia. The two locations showed dense cover of $U$. tenuifolia between 3 to $18 \mathrm{~m}$, combined with other common Caribbean coral species, such as Orbicella spp., Millepora alcicornis, Porites astreoides, Mycethophyllia spp. and brain corals (Diploria and Pseudodiploria), among others. Palo is clearly a more diverse type of coral reef with higher water motion 

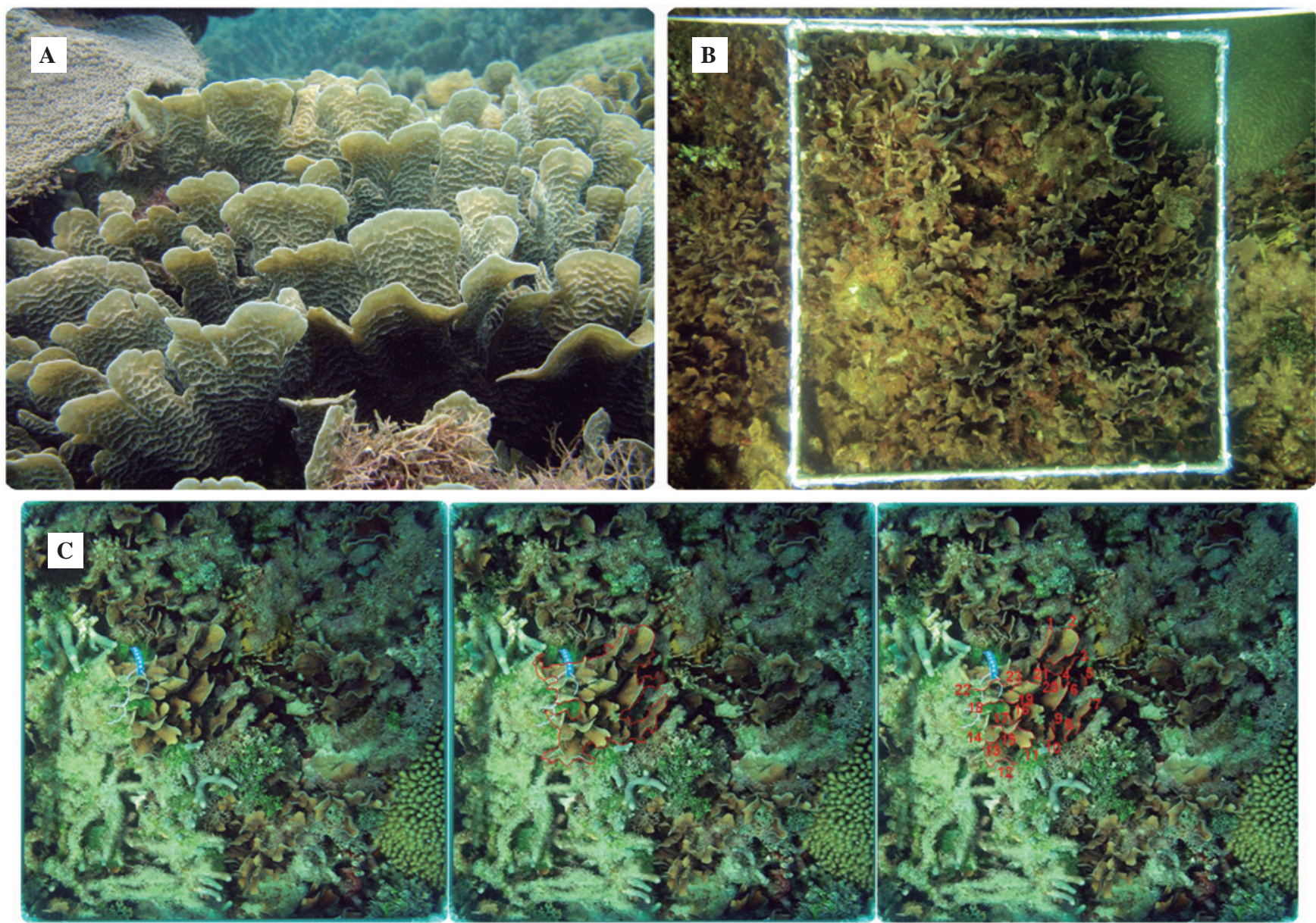

Figure 1. Images of Undaria tenuifolia Dana at Playita, $10 \mathrm{~m}$ deep, Barú island. A. Detail of a colony. B. A $1 \mathrm{~m}^{2}$ quadrat for estimating $U$. tenuifolia coral cover (note the species abundance). C. A tagged colony photographed within a $25 x 25$ frame for growth measurements and monitoring, showing (left to right) the raw image, the polygon (red) of its area and the blade edges numbered.

and coarser sediments whereas Playita is a calmer area with notable fine sedimentation due to its proximity with a coastal estuary (Ciénaga de los Vasquez).

\section{Size distribution and abundance}

Two perpendicular (cross-like) $30 \mathrm{~m}$ belt transects were located at the two sites (total area studied for each location: $116 \mathrm{~m}^{2}$ ). Each transect was photographed every 6 months starting in April 2006 and finishing in April 2007. A $1 \mathrm{~m}^{2}$ quadrant was used as grid for guiding the photographs (Figure 1B). A colony was defined as any area of coral tissue growing independently and physically separated from its neighbors. All colonies were first assigned in 2006 to one of four size classes (I: $\mathrm{x}<47.35 \mathrm{~cm}^{2}$; II: $47.35 \mathrm{~cm}^{2}<\mathrm{x}<$ $109 \mathrm{~cm}^{2}$; III: $109 \mathrm{~cm}^{2}<\mathrm{x}<224 \mathrm{~cm}^{2}$ and IV; $\mathrm{x}>224 \mathrm{~cm}^{2}$ ). The population was divided in this way in order to include the range of colony sizes found at the two locations, while maintaining an appropriate sample size for each size class. Dividing up the population into natural cohorts would have increase the number of size classes, due to the larger amount of small colonies, but would have increase the error around the transition probabilities. Coral percent cover (projected area) was measured with ImageJ Software (NIH) from each 1 $\mathrm{m}^{2}$ quadrant photographed. Cover data was log-transformed in order to reduce non-normality and heteroscedasticity, then tested for normal distribution (single KolmogorovSmirnov test) and compared with general linear models (ANOVA) to test one dependent variable against one or more independent factors (SPSS).

\section{Colony growth}

In order to determine clonal processes, a total of 80 colonies (roughly half in each site) along a $50 \mathrm{~m}$ belt transect, different from the $30 \mathrm{~m}$ cross belt transect, was haphazardly chosen at each location. The colonies were marked with aluminum tags for numerical individual recognition. The colonies were monitored the following dates: April 2006, October 2006 and April 2007. Photographs were taken using a $25 \times 25 \mathrm{~cm}$ quadrant as reference grid (Figure 1C). From each photographed colony, the net change in projected area, as well as fission, partial dead area, bleached area, and fusion were noted and measured with ImageJ after distortion correction using the 
frame and free-transformation in Adobe Photoshop (Lasker et al., 2003). Per-colony percent growth was calculated as the change between final and initial area (after a year) divided by the initial area. Partial mortality was defined as the percolony area of bleached and/or algae colonized coral tissue spotted at every monitored interval during the study period. The results were analyzed also using general linear models (ANOVA). We analyzed if the size class, sampling time or location affected mortality. Fusion was recorded as the union of two separate colonies that grew adjacent and came into contact, joining their tissues and skeletons. Fission was noted when a single colony turned into two or more smaller colonies. All measurements were done in $\mathrm{cm}^{2}$.

In addition to the data collected from the photographs, two in situ measurements of growth were taken in a subset of colonies outside the belt transects: (1) buoyant weight performed on April 2006, October 2006 and April 2007 at each location and (2) an Alizarin-red S vital staining of colonies performed only in April 2007 in one location. The in situ buoyant weight was performed on $\mathrm{n}=25$ colonies following the technique described by (Bablet, 1985) and (Davies, 1989), which allows the accurate measurement of weight change, without killing the colonies, permitting repeated measurements of growth. The calculations were taken following the equation given by Bablet (1985):

$$
W_{(\text {real })}=\left(\frac{P_{(\text {water })}^{\prime}}{1}\right)-\left[\frac{D_{(\text {water })}}{D_{(\text {aragonite })}^{\prime}}\right]
$$

Were, $\mathrm{W}_{\text {(real) }}$ : Real weight of the Calcium carbonate skeleton of the colony (g), $\mathrm{P}_{\text {(water) }}$ : Apparent weight of the colony inside the water (g); $\mathrm{D}_{\text {(water) }}$ : Seawater density at the moment of the experiment $\left(\mathrm{g} \mathrm{cm}^{-3}\right)$ and $\mathrm{D}_{\text {(aragonite) }}$ : Aragonite density $=2.39 \mathrm{~g} \mathrm{~cm}^{-3}$. Percentage growth was calculated as the change between final and initial weight divided by the initial weight. Alizarin red S staining was applied to 10 randomly selected colonies from each of size classes I and II in Playita, in April 2007 as a supporting data for the growth rates found in the photographic censuses. Alizarin red $\mathrm{S}$ is a vital dye commonly used in corals, allowing colony size recognition at the time of staining, due to its incorporation into the coral skeleton (Hughes \& Jackson, 1985; Lamberts, 1978). With only purpose to have a short-term measure of growth in $U$. tenuifolia, the colonies were incubated for $1 \mathrm{~d}$ in individual plastic bags with an alizarin solution (20 $\mathrm{mg} \mathrm{l}^{-1}$ ). Colonies were collected 47 days after staining and the growth was measured as the distance between the stain and the new colony boundary without involving any cutting of the colonies because the stain line was visible from the surface. A total of ten measurements per colony were taken from haphazardly chosen areas of the terminal edge $(n=5)$ and inner edges $(\mathrm{n}=5)$.

\section{Size-class matrix model}

A size matrix model was constructed following Hughes (1984) for clonal coral species. In general, the model projects a coral population structure at time $t+1$ from the measured size structure at time $t$. The general model was defined as:

$$
X(t+1)=T \cdot \bar{\chi}(\mathrm{t})
$$

Where: $\chi(t)$ is a column vector describing the population size structure at time $t$. $T$ is the transition matrix of probabilities within the size classes, taking into account the probability of the colonies: (1) remaining in the same size class, (2) growing to next size classes or (3) shrinking to smaller size classes (Caswell, 2001; Dullo, 2005; Fong \& Glynn, 2000; Hughes, 1984). The transition probabilities were obtained from the tagged colonies, which were individually followed through photographic censuses during the study period. It is important to mention that this transition model could project, but not accurately predict, the future of the population due to the assumption that the size structure and transition matrix values remain constant, which is unlikely to happen (Caswell, 2001; Dullo, 2005; Lefkovitch, 1965). The transition probabilities were obtained from the colonies tagged and individually followed photographic censuses during the study period. It is important to mention that this transition model could project, but not accurately predict the future of the populations due to the assumption that the variables remain constant, which is unlikely to happen. In order to look at the overall growth of the population monitored $(n=50)$, a population diagram was developed. The diagram takes into account all the colonies as initial population and does not treat the size classes' probabilities independently. The final number of tagged colonies tagged included in the model changed from 80 to 50 colonies due to algae colonization over the tags, hindering colony identification and monitoring.

\section{Results}

\section{Demography and abundance}

The two sites chosen were highly diverse, presenting areas with a high dominance of $U$. tenuifolia, to areas with more species present. Coral percent cover of $U$. tenuifolia differed significantly between the two locations (ANOVA, $\mathrm{F}=137$; $P<0.001$ ). Playita had higher $U$. tenuifolia cover with an average per $1 \mathrm{~m}^{2}$ photo quadrat of $27.4 \pm 3.5 \%$ (mean \pm $\mathrm{SD}$ ) (Figure 2, grey boxes) compared to Palo, which had an average cover of $3.6 \pm 0.6 \%$ (mean \pm SD) (Figure 2). In general, $U$. tenuifolia cover was significantly different among size classes, the largest size class having the greatest cover. But differences in coral cover between size classes depended on the location (significant location by size class interaction), with IV size class having the greatest cover at Palo whereas II was the size class with the greatest cover at Playita (ANOVA, Table 1).

Palo reef exhibited a decrease in the number of colonies for all size-classes from 364 colonies in April 2006 down to 194 colonies in October 2006. From October 2006 to April 2007 it remained relatively stable for all size classes, the 

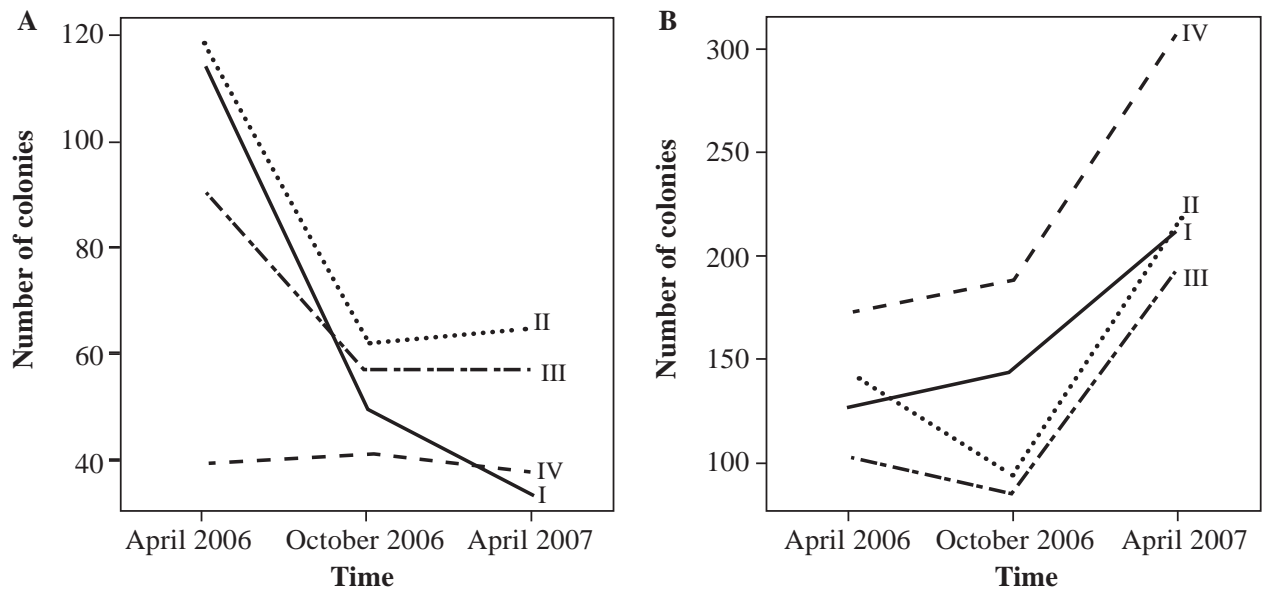

Figure 2. Percent cover of Undaria tenuifolia from the three times monitored, starting April 2006 and finishing April 2007 in the two locations monitored in the Southern Caribbean.

Table 1. Results from the ANOVA test for: coral cover $\left(1 \mathrm{~m}^{2}\right)$ of Undaria tenuifolia as the dependent variable against size classes, reef (Playita vs. Palo), and time interval; $\mathrm{n}=116$ photo quadrants measured in each of two locations at three sampling times (April 2006, October 206, April 2007) (*denotes significant values at $P<0.05$ ).

\begin{tabular}{lcc}
\hline Source of Variation & F & P value \\
\hline Size & 50.730 & $0.003^{*}$ \\
\hline Reef & 0.679 & 0.463 \\
Time & 0.179 & 0.843 \\
\hline Size * Reef & 47.453 & $<0.001 *$ \\
\hline Size * Time Interval & 3.475 & 0.078 \\
\hline Reef * Time Interval & 4.628 & 0.054 \\
Size * Reef * Time Interval & 0.797 & 0.572 \\
\hline
\end{tabular}

total number of colonies increasing slightly to 210 (Figure 3A), which could imply a balance between death rate and new colonies added from clonal processes. Playita reef, on the other hand, presented a variable number of colonies throughout the year; the amount of colonies in size classes II and III decreased from April 2006 to October 2006 and the number of colonies for every size-class increased from October 2006 to April 2007 (Figure 3B). Since the total amount of colonies changed from 548 in April 2006 to 930 colonies in April 2007 this suggests that the colony death rate was lower than the addition of new colonies.

\section{Colony tissue mortality, fusion and fission}

Almost all tagged colonies exhibited clonal processes. Partial mortality per-colony was not significantly dependent on size class or sampling time but significantly differed between the two reefs (ANOVA, $P<0.01$ ). In general, the amount of colonies without injury was $51.8 \%$ regardless of size. Partial or entire tissue mortality occurred in $48.2 \%$ of the colonies with a mean per-colony tissue loss of $34.6 \% \pm$
30.1 (mean \pm SD). Whole colony mortality was at least $4 \%$ in both locations. Interestingly, the dead colonies found belonged to the IV size class. Thirty colonies were lost or not found. Interestingly, the colonies found dead belonged to the IV size class. Few colonies presented fusion. Only two colonies out of the final 50 presented fusion with a neighboring colony and both cases transferred them to the next larger size class (from size class I to II and from size class III to IV). Fission was a common process, particularly between October 2006 and April 2007. Fourteen colonies out of the 50 exhibited fission, and almost all of these belonged to the IV size class, except one colony from the III size class. Colony size class transitions coming from fission were observed as follows: five colonies shifted from size class IV to size class III; four colonies moved from size class IV to size class II, two colonies passed from size class IV to size class I; two colonies from size class IV and one from size class III presented fission, but it did not represent a size class transition.

\section{Colony Growth}

There were no significant differences in per-colony percent growth between the two time intervals or between locations (ANOVA, $P>0.05$ ). Thus, measurements from both intervals were used to calculate colony growth. Percent growth was then compared among size classes by locations. Colonies from size classes I and II grew to double their initial area (Figure 4). Colonies from size class IV commonly presented loss of tissue, oftentimes due to fission events. Fission was mostly observed in the largest size colonies monitored, which on average loss tissue (Figure 4).

The relative semi-annual growth percentage obtained from the buoyant weight change of tagged colonies showed no statistical correlation with the initial colony weight (Linear regression, $\left.\mathrm{n}=26, r^{2}=0.02, \mathrm{~F}=0.481 ; P=0.494\right)$. The mean semi-annual percent growth was $4.33 \pm 32 \%$ (mean $\pm \mathrm{SD}$ ). 


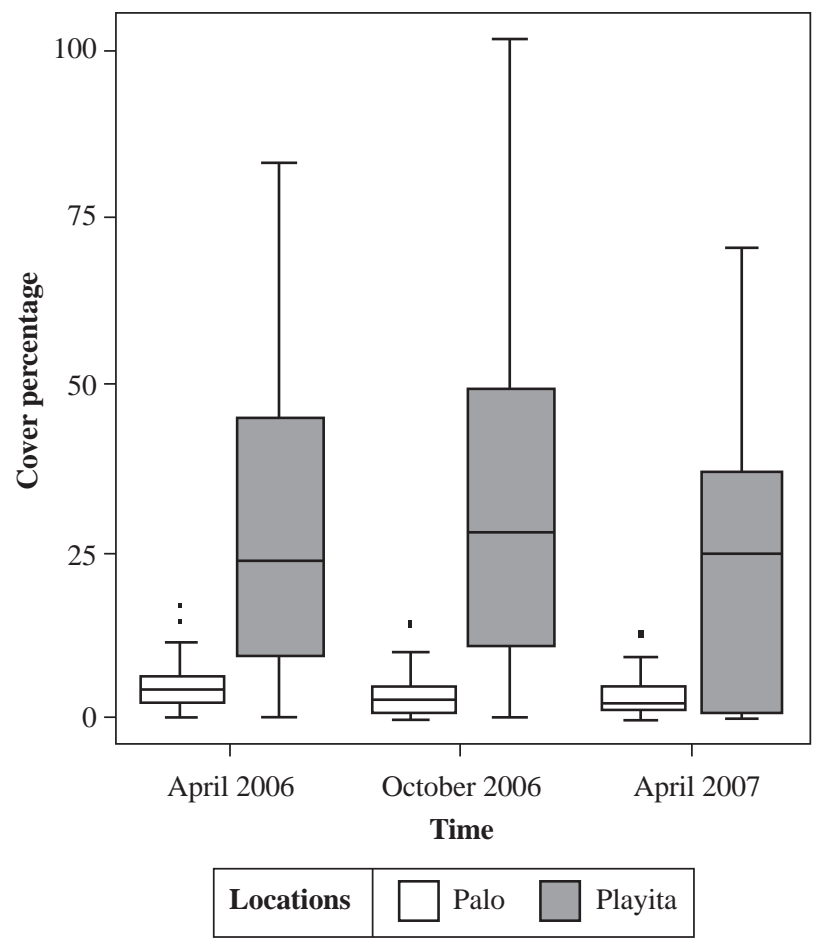

Figure 3. Number of colonies per size class of Undaria tenuifolia, throughout the study period (April 2006 to April 2007). Empty boxes. Colonies at Palo. Grey boxes. Colonies at Playita.

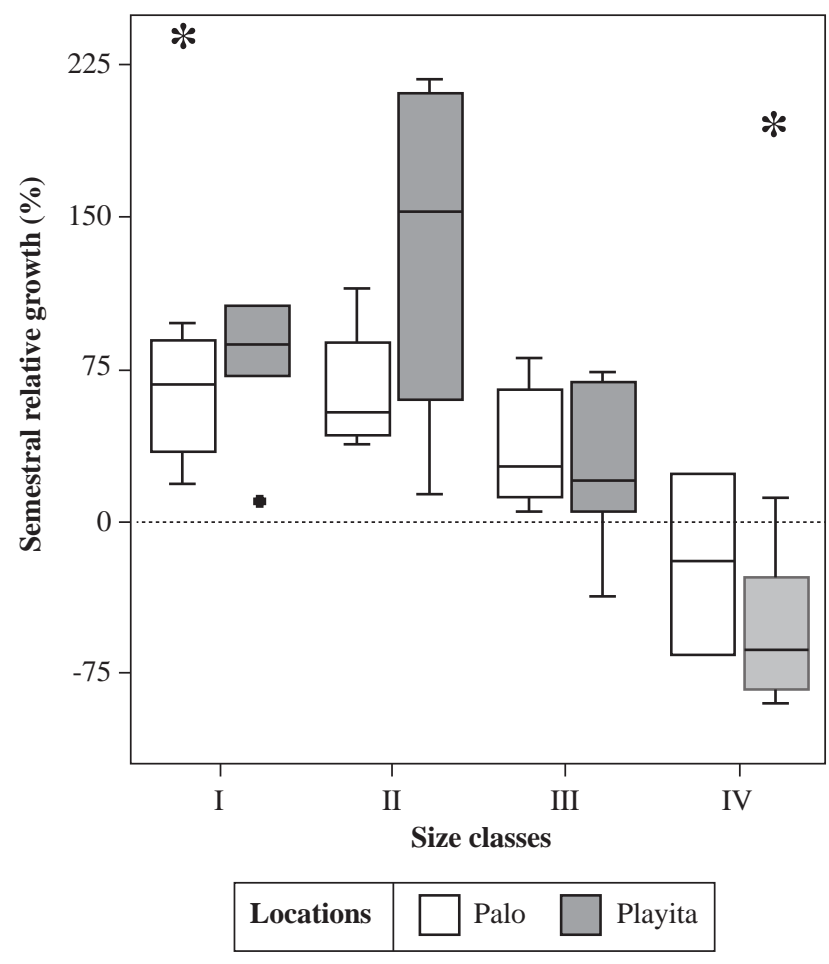

Figure 4. Net colonial growth of colonies from Undaria tenuifolia determined by the photographic census for the different size classes and locations. (*) Extreme values due to fusion processes. ( ) Atypical value.
Weight classes were not considered due to the small number of colonies $(n=25)$. The Alizarin red S staining, though applied to a reduced number of colonies $(n=10)$ during 47 days, corroborated a rapid growth in $U$. tenuifolia colonies. Per-colony monthly growth percentage presented a mean of $10 \%$ with a minimum of $0.32 \%$ and a maximum of $39 \%$ of the original size. Additionally, daily growth rates in the edges had a mean of $0.046 \pm 0.01 \mathrm{~mm} \mathrm{~d}^{-1}$ (mean \pm SD) for the terminal edges of the colonies and a $0.027 \pm 0.01 \mathrm{~mm} \mathrm{~d}^{-1}$ (mean $\pm \mathrm{SD}$ ) for the inner edges.

\section{Size transition matrix}

Throughout the study period, size classes I and III presented similar probabilities of either remaining in the same size class or growing into the next-large size class (Figure 5). Size class II showed a high probability of growing into larger size classes (Figure 5). In contrast, the largest size class had a higher probability of moving backward to smaller size classes than remaining in the same size class; it was the only size class where total colony mortality occurred (Figure 5).

The size frequency distribution predicted from the model was similar to the size frequency distribution observed in the field (G-test, $\mathrm{G}=6.1983, \mathrm{df}=3, P=0.10$ ). In order to project a future population of $U$. tenuifolia in the locations monitored, the transition matrix was tested with the cover data obtained (data not shown). Briefly, the cover data was used as the column vector describing the population size structure at time $t$ with the same transition matrix. When the cover data was combined with the transition matrix, significant differences in the size distribution observed were found at each location (Palo, $n=364$; G-test, $\mathrm{G}=$ 18.937, $\mathrm{df}=3, P<0.01$; Playita, $\mathrm{n}=548$; G-test, $\mathrm{G}=79.53$, $\mathrm{df}=3, P<0.001)$.

\section{Discussion}

Clonal processes, particularly fission, comprised an important component in $U$. tenuifolia growth strategy. In the two reefs studied at a Southern Caribbean coral reef (Cartagena, Colombia), a large amount of colonies from small size classes were continuously produced mostly from fission and notable at Playita. Fission, as seen in the transition matrix, seems to give this coral an advantage to become a dominant species. Fission in $U$. tenuifolia could be produced in 2 ways: (1) colony division due to a physiological mechanism where separate (but still attached) ramets are generated without jeopardizing the original ramet, improving the genet longevity and, (2) mechanical fragmentation, where loose fragments reattach and regrow. These two processes could be highly correlated with environmental factors (e.g., high tides, storm waves, high surface sea temperature), competition with algae, sponges and other coral species (Aronson et al., 2002b; Aronson et al., 2014), which normally occur in reefs. The fast colonial growth, together with fission appear to yield a dynamic growth strategy that allows U. tenuifolia to avoid the high susceptibility to 


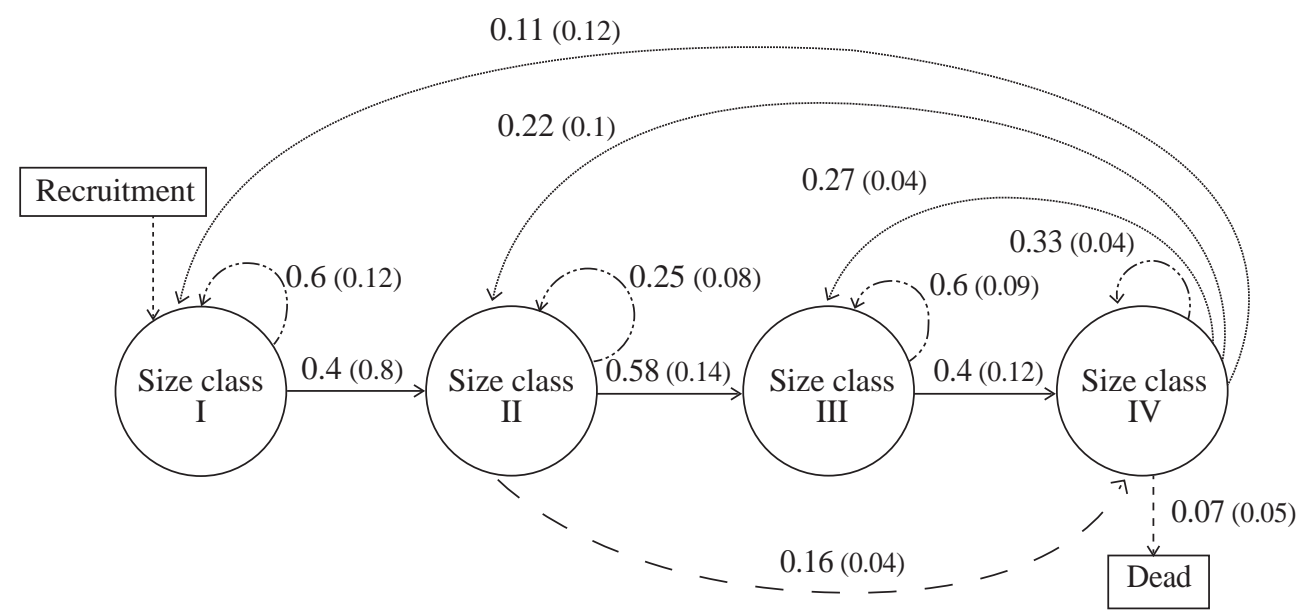

Figure 5. Diagram of the transition matrix for Undaria tenuifolia taking into account the clonal process observed in tagged colonies ( $\mathrm{n}=50$ ). The numbers represent the transition probabilities for each size class. The numbers in parenthesis are the percentage of the entire population shifts observed between April 2006 and April 2007. The type of line means different events. $(\cdots \cdots) \mathrm{P} \wedge$ to shrink to a smaller size class. (-- - --) $\mathrm{P}^{\wedge}$ to stay in the same size class. (---) $\mathrm{P}^{\wedge}$ to pass to the next size class. (- - -) $\mathrm{P}^{\wedge}$ to pass to a larger size class (fusion). (- - -) $\mathrm{P}^{\wedge}$ of Recruitment and Death. Death defined as total mortality. There are not probabilities for death in size classes I, II and III because it was not observed; however, it was expected due to the lost of many colonies during the period studied.

competition that is often associated with early coral postsettlement (Connolly \& Muko, 2003; Hagedorn et al., 2006; Highsmith, 1982). Fission is a common life history characteristic present in many hard corals (Curaçao: Bak \& Luckhurst, 1980, Jamaica: Hughes \& Jackson, 1985). In turn, this high proportion of small size colonies generates a natural size distribution skewed towards smaller size classes, which appear to be related to environmental conditions such as strong currents or storms that favor population growth by means of fission (Meesters et al., 2001).

Fusion, on the other hand, may be a size independent process in $U$. tenuifolia but was not as commonly observed, as it was fission. The mechanisms initiating and controlling fusion are not clearly known in corals, but they might be related with allorecognition systems for clonemates, which are well understood in other groups of invertebrates (see review in Hughes, 2005). This process increases small colony survival, as well as many other benefits to the population (Hughes et al., 1992; Hughes \& Jackson, 1980). Nonetheless, longer periods of monitoring are necessary to accurately estimate fusion rates in $U$. tenuifolia.

The local population of $U$. tenuifolia by itself contributed to up to $27 \%$ of the total cover in one of the study sites (Playita), suggesting its potential dominant role in the coral community structure at Southern Caribbean reefs. These mechanisms enable $U$. tenuifolia to colonize semi-exposed shallow fore-reefs with a high probability of survivorship (Dullo, 2005; Sebens et al., 2003). This comb-like growth mode may also lead to the exclusion of common coral competitors such as Porites spp. that cannot easily dominate the shallow fore-reefs as $U$. tenuifolia does (Aronson \& Precht, 2000; Aronson et al., 2000, 2014; Sebens et al., 2003).
U. tenuifolia also avoids overgrowth by other competitive corals by decreasing free substrate, thus facilitating its dominance (Sebens et al., 2003).

\section{Undaria tenuifolia: dominant or opportunistic?}

Reef cores dating back thousands of years indicate that $U$. tenuifolia has been a dominant reef species at various times in history in the Southern Caribbean, before the recent coral reef decline (Vernette, 1985; Vernette et al., 1992). However, there are findings from the last few decades suggesting it is an opportunistic species rather than a dominant one (Aronson et al., 1998, 2014). It appears that U. tenuifolia tends to be a dominant species when its competitors are declining under unfavorable conditions. This dominance, or rather opportunistic behavior, can be mediated by the growth strategies observed in $U$. tenuifolia. In addition, to its comb-like conformation of colonies, notably adapted to repel sedimentation (personal observation). In this comblike conformation, the colonies and multiple ramets may fuse, perhaps diminishing the mortality risk or probably altering the local microenvironment to its benefit. This coral aggregation is also helped out by the plastic indeterminate growth of this type of modular organisms (Caswell, 2001). Although the polyp size is genetically determined, a coral colony may grow indeterminately (Connolly \& Muko, 2003; Hughes et al., 1992; Lasker \& Sánchez, 2002; Sebens, 2003).

As mentioned, $U$. tenuifolia face environmental stress factors such as high water temperatures or terrestrial run-offs from rivers such as Magdalena and Sinú (Restrepo et al., 2006; Velásquez et al., 2011). Previously, it has been considered that $U$. tenuifolia is a susceptible species to bleaching, exhibiting low or negligible recovery after a bleaching 
disturbances caused by high temperatures (Aronson et al., 2000; Robbart et al., 2004). This low recovery has been related to (1) the low amount of heat shock protein (HSP) presented in U. tenuifolia (Robbart et al., 2004) and (2) its monotypic symbiosis with a low temperature tolerant type of Symbiodinium (Baker, 2003; LaJeunesse, 2002). High sea surface temperature (SST) has been the condition observed as the trigger for the decrease of $U$. tenuifolia populations in the northwestern Caribbean (Aronson et al., 2002a; Aronson and Precht, 2000; Aronson et al., 1998). Further high SSTs together with a reduced grazer fish density, and high algae and sponge cover would impede the $U$. tenuifolia population's recovery (Aronson et al., 2002b; Bellwood et al., 2004; Connell, 1997; Jackson, 2001). However, in the study area, Barú island, Colombia, U. tenuifolia contains a rather generalist symbiont, Symbiodinium C3 (Camargo et al., 2009), which has also been considered as a stress- and high temperature-tolerant zooxanthellae type elsewhere (Hume et al., 2013). Whether the southern Caribbean populations of $U$. tenuifolia are more resistant to heat disturbances than the northwestern populations remains unknown.

One of the motivations of this study was the fact that there is a continued extraction of $U$. tenuifolia as a souvenir near Cartagena, Colombia. Although it is unknown the extent and effect of the extraction on the affected populations, fortunately it is clear that this is one the corals with higher growth rates in the Caribbean. This parallels what was also found near Cartagena on the harvested octocoral Antillogorgia acerosa, which is also among the faster growing gorgonian corals of the Caribbean (Cadena \& Sánchez, 2010). To accurately predict the population response due to a sustain harvest in a coral species additional factors affecting the growth strategy of $U$. tenuifolia would need to be measured. Yet, the size-based approach used in this study offered a practical advantage in a shortterm observation situation, generating a "time- invariant" transition model (Yoshioka, 1994). Overall, the size matrix model showed how dynamic the colony, as an individual, could be, which is characteristic of an opportunistic coral. The high survivorship of $U$. tenuifolia after clonal fragmentation, as well as its high growth rate, suggests that this is a potential species to be cultured at mid-water gardening conditions (Rinkevich, 2014), where a more sustainable production of the species appears feasible.

\section{Acknowledgments}

This study was funded by Fondo Colombiano de Investigaciones Científicas y Proyectos Especiales Francisco José de Caldas COLCIENCIAS (Project No. 1204-09-17774) and Universidad de los Andes (Departamento de Ciencias Biológicas-Facultad de Ciencias). Special thanks to: J. Cadena, N. Manrique, V. Piñeros, C. Camargo, other members of BIOMMAR (UniAndes), C. Martinez and J. Schot (Cartagena) for their valuable help during field work. We thank H. Contreras from the Physics Department,
Universidad los Andes, for his helpful advice and comments. Comments from Sven Zea and an anonymous reviewer are greatly appreciated.

\section{Conflict of interests}

The authors declare no conflicts of interest of any kind.

\section{Bibliography}

Aronson R.B., Hilbun N.L., Bianchi T.S., Filley T.R., \& Mckee B.A. (2014) Land use, water quality, and the history of coral assemblages at Bocas del Toro, Panama. Marine EcologyProgress Series, 504: 159-170.

Aronson R.B., Macintyre I.G., Precht W.F., Murdoch T.J.T., \& Wapnick C.M. (2002a) The expanding scale of species turnover events on coral reefs in Belize. Ecological Monographs, 72: 233-249.

Aronson R.B., Macintyre I.G., Precht W.F., Murdoch T.J.T., \& Wapnick C.M. (2002b) The expanding scale of species turnover events on coral reefs in Belize. Ecological Monographs, 72: 233-249.

Aronson R.B., \& Precht W.F. (2000) Herbivory and algal dynamics on the coral reef at Discovery Bay, Jamaica. Limnology \& Oceanography, 45: 251-255.

Aronson R.B., \& Precht W.F. (1995) Landscape patterns of reef coral diversity: a test of the intermediate disturbance hypothesis. Journal of Experimental Marine Biology and Ecology, 192: 1-14.

Aronson R.B., \& Precht W.F. (1997) Stasis, biological disturbance, and community structure of a Holocene coral reef. Paleobiology, 23: 326-346.

Aronson R.B., Precht W.F., \& Macintyre I.G. (1998) Extrinsic control of species replacement on a Holocene reef in Belize: the role of coral disease. Coral Reefs, 17: 223-230.

Aronson R.B., Precht W.F., Macintyre I.G., \& Murdoch T.J.T. (2000) Ecosystems: Coral bleach-out in Belize. Nature, 405: 36-36.

Aronson R.B., Precht W.F., Toscano M.A., \& Koltes K.H. (2002c) The 1998 bleaching event and its aftermath on a coral reef in Belize. Marine Biology, 141: 435-447.

Bablet J.P. (1985) Report on the growth of a scleractinia (Fungia paumotensis), In Proceedings 5th International Coral Reef Symposium, Tahiti, pp. 361-365.

Baker A.C. (2003) Flexibility and specificity in coral-algal symbiosis: diversity, ecology, and biogeography of Symbiodinium. Annual Review of Ecology, Evolution, and Systematics, 34: 661-689.

Bak R.P.M., \& Luckhurst B.E. (1980) Constancy and change in coral reef habitats along depth gradients at Curaçao. Oecologia, 47: 145-155.

Bellwood D.R., Hughes T.P., Folke C., \& Nystrom M. (2004) Confronting the coral reef crisis. Nature, 429: 827-833.

Brazeau D.A., \& Lasker H.R. (1992) Growth Rates and Growth Strategy in a Clonal Marine Invertebrate, the Caribbean Octocoral Briareum asbestinum. Biological Bulletin, 183: 269-277. 
Cadena N.J., \& Sánchez J.A. (2010) Colony growth in the harvested octocoral Pseudopterogorgia acerosa in a Caribbean coral reef. Marine Ecology, 31: 566-573.

Camargo C., Maldonado J., Alvarado E., Moreno-Sánchez R., Mendoza S., Manrique N., Mogollón A., Osorio J., Grajales A., \& Sánchez J.A. (2009) Community involvement in management for maintaining coral reef resilience and biodiversity in southern Caribbean marine protected areas. Biodiversity and Conservation, 18: 935956.

Caswell H. (2001) Matrix population models: construction, analysis, and interpretation 2nd ed. Sunderland, Mass.: Sinauer Associates.

Cendales M.H., Zea S., \& Díaz J.M. (2002) Geomorfología y unidades ecológicas del complejo de arrecifes de las Islas del Rosario e Isla Barú (Mar Caribe, Colombia). Rev. Acad. Colomb. Cienc, 26: 497-510.

Chadwick-Furman N.E., Goffredo S., \& Loya Y. (2000) Growth and population dynamic model of the reef coral Fungia granulosa Klunzinger, 1879 at Eilat, northern Red Sea. Journal of Experimental Marine Biology and Ecology, 249: 199-218.

Clark-Tapia R., Alfonso-Corrado C., Eguiarte L.E., \& MolinaFreaner F. (2005) Clonal diversity and distribution in Stenocereus eruca (Cactaceae), a narrow endemic cactus of the Sonoran Desert. American Journal of Botany, 92: $272-278$

Connolly S.R., \& Muko S. (2003) Space pre-emption, sizedependent competition, and the coexistence of clonal growth forms. Ecology, 84: 2979-2988.

Davies P.S. (1989) Short-term growth measurements of corals using an accurate buoyant weighing technique. Marine Biology, 101: 389-395.

Díaz-Pulido G., Sánchez J.A., Zea S., Díaz J.M., \& GarzónFerreira J. (2004) Esquemas de distribución espacial en la comunidad bentónica de arrecifes coralinos continentales y oceánicos del Caribe colombiano. Revista de la Academia Colombiana de Ciencias, 28: 337-347.

Dullo W.C. (2005) Coral growth and reef growth: a brief review. Facies, 51: 37-52.

Eakin C.M., Morgan J.A., Heron S.F., Smith T.B., Liu G., Alvarez-Filip L., Baca B., Bartels E., Bastidas C., \& Bouchon C. (2010) Caribbean corals in crisis: record thermal stress, bleaching, and mortality in 2005. PLoS One, 5: e13969.

Fong P., \& Glynn P.W. (2000) A regional model to predict coral population dynamics in response to El Niño southern oscillation. Ecological Applications, 10: 842-854.

Foster N.L., Baums I.B., Sanchez J.A., Paris C.B., Chollett I., Agudelo C.L., Vermeij M.J., \& Mumby P.J. (2013) Hurricane-driven patterns of clonality in an ecosystem engineer: the Caribbean coral Montastraea annularis. PLoS One, 8: e53283.

Glynn P.W. (1984) Widespread coral mortality and the 1982-83 El Niño warming event. Environmental Conservation, 11: 133-146.
Guest J.R., Baird A.H., Maynard J.A., Muttaqin E., Edwards A.J., Campbell S.J., Yewdall K., Affendi Y.A., \& Chou L.M. (2012) Contrasting patterns of coral bleaching susceptibility in 2010 suggest an adaptive response to thermal stress. PLoS One, 7: e33353.

Hagedorn M., Pan R., Cox E.F., Hollingsworth L., Krupp D., Lewis T.D., Leong J.C., Mazur P., Rall W.F., MacFarlane D.R., Fahy G., \& Kleinhans F.W. (2006) Coral larvae conservation: Physiology and reproduction. Cryobiology, 52: 33-47.

Highsmith R.C. (1982) Reproduction by fragmentation in corals. Marine Ecology-Progress Series, 7: 207-226.

Hughes R.N. (2005) Lessons in modularity: the evolutionary ecology of colonial invertebrates. Scientia Marina, 69: 169-179.

Hughes T.P. (1984) Population Dynamics Based on Individual Size Rather than Age: A General Model with a Reef Coral Example. The American Naturalist, 123: 778.

Hughes T.P., Ayre D., \& Connell J.H. (1992) The evolutionary ecology of corals. Trends in Ecology \& Evolution, 7: 292295.

Hughes T.P., Baird A.H., Bellwood D.R., Card M., Connolly S.R., Folke C., Grosberg R., Hoegh-Guldberg O., Jackson J.B.C., Kleypas J., Lough J.M., Marshall P., Nystrom M., Palumbi S.R., Pandolfi J.M., Rosen B., \& Roughgarden J. (2003) Climate change, human impacts, and the resilience of coral reefs. Science, 301: 929-933.

Hughes T.P., \& Jackson J.B.C. (1980) Do Corals Lie About Their Age? Some Demographic Consequences of Partial Mortality, Fission, and Fusion. Science, 209: 713-715.

Hughes T.P., Jackson J.B.C. (1985) Population Dynamics and Life Histories of Foliaceous Corals. Ecological Monographs, 55: $141-166$

Hume B., Angelo C. D’, Burt J., Baker A.C., Riegl B., \& Wiedenmann J. (2013) Corals from the Persian/Arabian Gulf as models for thermotolerant reef-builders: Prevalence of clade C3 Symbiodinium, host fluorescence and ex situ temperature tolerance. Marine pollution bulletin, 72: 313322.

Jackson J.B.C. (2001) What was natural in the coastal oceans? Proceedings of the National Academy of Sciences of the United States of America, 98: 5411-5418.

LaJeunesse T.C. (2002) Diversity and community structure of symbiotic dinoflagellates from Caribbean coral reefs. Marine Biology, 141: 387-400.

Lamberts A.E. (1978) Coral growth: alizarin method. Coral reefs: research methods. UNESCO, Paris, 523-527.

Langmead O., Sheppard C. (2004) Coral reef community dynamics and disturbance: a simulation model. Ecological Modelling, 175: 271-290.

Lasker H.R. (1990) Clonal Propagation and Population Dynamics of a Gorgonian Coral. Ecology, 71: 1578-1589.

Lasker H.R. (1991) Population growth of a gorgonian coral: equilibrium and non-equilibrium sensitivity to changes in life history variables. Oecologia, 86: 503-509. 
Lasker H.R., Boller M.L., Castanaro J., \& Sánchez J.A. (2003) Modularity and determinate growth in a gorgonian coral. The Biological Bulletin, 205: 319-330.

Lasker H.R., \& Coffroth M.A. (1999) Responses of Clonal Reef Taxa to Environmental Change. American Zoologist, 39: 92-103.

Lasker H.R., \& Sánchez J.A. (2002) Allometry and Astogeny of modular organisms, In Reproductive Biology of Invertebrates, pp. 207-253. Ed R. N. Hughes. New York: John Wiley.

Lefkovitch L.P. (1965) The study of population growth in organisms grouped by stages. Biometrics, 21: 1-18.

López-Angarita J., Moreno-Sánchez R., Maldonado J.H., Sánchez J.A. (2014) Evaluating Linked Social-Ecological Systems in Marine Protected Areas. Conservation Letters, 7: 241-252.

Meesters E.H., Hilterman M., Kardinaal E., Keetman M., de Vries M., \& Bak R.P.M. (2001) Colony size-frequency distributions of scleractinian coral populations: spatial and interspecific variation. Marine Ecology-Progress Series, 209: 43-54.

Restrepo J.D., Zapata P., Diaz J.A., Garzon-Ferreira J., \& Garcia C.B. (2006) Fluvial fluxes into the Caribbean Sea and their impact on coastal ecosystems: The Magdalena River, Colombia. Global and Planetary Change, 50: 33-49.

Riegl B., Purkis S.J., Keck J., \& Rowlands G.P. (2009) Monitored and modeled coral population dynamics and the refuge concept. Marine Pollution Bulletin, 58: 24-38.

Rinkevich B. (2014) Rebuilding coral reefs: does active reef restoration lead to sustainable reefs? Current Opinion in Environmental Sustainability, 7: 28-36.

Robbart M.L., Peckol P., Scordilis S.P., Curran H.A., \& BrownSaracino J. (2004) Population recovery and differential heat shock protein expression for the corals Agaricia agaricites and A.tenuifolia in Belize. Marine EcologyProgress Series, 283: 151-160.

Sánchez J.A. (1995) Benthic communities and geomorphology of the Tesoro Island reefs, Colombian Caribbean. Anales del Instituto de Investigaciones Marinas de Punta Betín, 24: 55-77.
Sebens K.P. (2003) The Ecology of Indeterminate Growth in Animals. Annual Review of Ecology and Systematics, 18: 371-407.

Sebens K.P., Helmuth B., Carrington E., \& Agius B. (2003) Effects of water flow on growth and energetics of the scleractinian coral Agaricia tenuifolia in Belize. Coral Reefs, 22: 35-47.

Soong K. (1991) Sexual reproductive patterns of shallow-water reef corals in Panama. Bulletin of Marine Science, 49: 832846.

Soong K., Lang J.C. (1992) Reproductive Integration in Reef Corals. Biol Bull, 183: 418-431.

Tanner J.E. (1997) Interspecific competition reduces fitness in scleractinian corals. Journal of Experimental Marine Biology and Ecology, 214: 19-34.

Velásquez J., López-Angarita J., \& Sánchez J.A. (2011) Evaluation of the FORAM index in a case of conservation. Biodiversity and Conservation, 20: 3591-3603.

Vernette G. (1985) La plateforme Continentale Caribe de Colombie (du debouche du Magdalena au Golfe de Morrosquillo). Tesis Doctoral a L’Universite de Bordeaux, Bordeaux.[Links].

Vernette G., Mauffret A., Bobier C., Briceno L., \& Gayet J. (1992) Mud diapirism, fan sedimentation and strike-slip faulting, Caribbean Colombian margin. Tectonophysics, 202: $335-349$.

Vollmer S.V., \& Palumbi S.R. (2006) Restricted Gene Flow in the Caribbean Staghorn Coral Acropora cervicornis: Implications for the Recovery of Endangered Reefs. Journal of Heredity, esl057.

Wilkinson C., \& Souter D. (2008) Status of Caribbean Coral Reefs after Bleaching and Hurricanes in 2005. Townsville: Global Coral Reef Monitoring Network, and Reef and Rainforest Research Center.

Yoshioka P.M. (1994) Size-specific life history pattern of a shallow-water gorgonian. Journal of Experimental Marine Biology \& Ecology, 184: 111-122. 